\title{
OBITUARY
}

\section{SIR JOHN MYRES: 1869-1954}

John Linton Myres began his life-long association with Greece and the British School at Athens in I891, when he visited the School's excavation at Megalopolis during an undergraduate visit to Greece. This visit was a turning-point in his career; after it his many-sided energies were devoted to the study of the Greek way of life, particularly during the early, formative period of Greek history. He returned to Athens in I892 as Craven Fellow and a Student of the School; travelled with Evans in Crete, with Paton in the Islands and Caria, and more widely in Mediterranean lands, where he knew most of the regions to which ancient Greek sailors and settlers penetrated. He dug in Cyprus, and, later, took part in the School's excavation at Palaikastro, where the Minoan sanctuary at Petsofà was his especial responsibility.

After I 895 he spent most of his life in Oxford, until 1907 as Student of Christ Church and, after an interlude as Gladstone Professor of Greek at Liverpool, as the first Wykeham Professor of Ancient History and Fellow of New College. His lectures as Professor were sometimes difficult to tie down in time and place, for they drew widely on his experiences in many lands and seas and his enormous reading; his great gift was in the vivid actuality with which he brought the past to life, and the flashes of insight which illuminated it with some far-fetched but fruitful analogy. His friends and pupils of many generations were continually stimulated by his enthusiasm, the breadth of his learning and interests, and his brilliant flow of conversation, full of new ideas and telling phrase.

As an archaeologist, his powerful visual memory and his gift for seeing likenesses led to some brilliant results. Though his main written work was in the field of ancient history, he laid the foundation of a scientific study of Cypriot antiquities with his catalogues of the Gyprus Museum and the Cesnola Collection, and made important contributions to the development of prehellenic studies, with his work on Kamares pottery and the early fabrics of the Cyclades.

The First World War brought him work after his own heart as Commander, R.N.V.R., in command of a caique with a roving commission in the Greek Islands and on the Turkish coast, gathering information and raiding cattle from the Turkish mainland. This was a life full of Homeric incident which lost nothing in the telling; he recalled with zest how, when he took passage in the relative comfort of a destroyer to report to base, he received ' hard lying' allowance denied him when on his caique or his shore excursions. He was awarded the O.B.E. and the Greek Order of George I for his services.

He was first elected to the Managing Committee of the School as long ago as I 895, and was elected an Honorary Student in 1896. In 1934 he became Chairman of the Managing Committee, in succession to George Macmillan, and remained Chairman until I947, when he was elected President. During the thirties he was in Athens for a part of nearly every year, took an active interest in the management of the School property and all the other activities of the School; his wonderful visual memory enabled him in his study in Oxford to discuss the siting of trees in the School garden or the field boundaries of the School's property at Knossos. He travelled widely in Greece at this time, and the inhabitants of many parts of the mainland and islands have still warm memories of him. It was his pleasure sometimes to recount stirring events of his war service, or of his earlier travels in the nineties; and after one evening in an 
Athens taverna when his younger hearers listened spellbound to these stories, he recalled that, like Odysseus, he had seen much and remembered more.

During the 1939-45 war he took on himself, with the departure of many younger men and women for war service, the greater part of the administration of the School, and rendered a particular service by editing the Annual. But increasing bodily infirmity began to make movement difficult, and for the last years of his life he was confined to his house in Oxford. One of his greatest pleasures now was to receive visits from young men just back from Greece and the Mediterranean, to hear the news from that part of the world, and to advise them in planning their travels. His mind was as active and scintillating as ever, and he was able in these years to complete Sir Arthur Evans' work on Scripta Minoa, to congratulate and encourage the younger men who were taking the steps which led to the reading of this script, and to publish Herodotus: Father of History. Herodotus was one of his earliest interests, and a historian for whom he had a fellow feeling. He was at work until the last, planning new books and producing a stream of articles and reviews. He was knighted in 1943 .

Though he could on occasion be a bonny fighter in criticism or controversy, he was a kindly man, and many of us recall acts of kindness and words of encouragement at the outset of our careers. In I 939 he was presented with a volume of the Annual containing studies by his pupils and friends; I believe that he wrote to all the contributors with an individual word of thanks and acute comment on the subject matter of their contribution. Many of us will recall a word, spoken in his study in Oxford or during a journey in Greece, which has set an old problem in a new light; and his books contain enough of these flashes to preserve his vivid appreciation of Mediterranean life for generations who have not known him in the flesh.

T. J. D. 